http://jmscr.igmpublication.org/home/

ISSN (e)-2347-176x ISSN (p) 2455-0450

crossref DOI: https://dx.doi.org/10.18535/jmscr/v8i5.29

\title{
A Study of Hepatopulmonary Syndrome in Patients of Chronic Liver Disease in North Indian Population
}

\author{
Authors \\ Dr Arun Kumar ${ }^{1}$, Dr Sumukh ${ }^{2}$ \\ ${ }^{1}$ Senior Consultant Physician, District Hospital, Jhansi \\ ${ }^{2}$ General Physician, Agra
}

\section{Introduction}

Liver is the largest organ of body and about $1.5 \mathrm{~kg}$ in average adult human. The basic functional unit of liver is lobule which is cylindrical, several $\mathrm{mm}$ in length and 0.8 to $2 \mathrm{~mm}$ in diameter. Cirrhosis is the most common condition associated with HPS. The cause of liver disease leading to portal hypertension does not seem to affect the development of HPS. Kennedy et $\mathrm{al}^{1,2}$ first defined HPS in 1977. HPS is characterized as a triad: liver disease, intrapulmonary vascular dilatation and arterial hypoxemia. HPS has been reported in patients with prehepatic portal hypertensionin the absence of chronic liver disease, in Budd-Chiari syndrome and even in patients with acute or chronic inflammatory liver disease without evidence of cirrhosis or portal hypertension ${ }^{3-7}$

The presence of HPS increases mortality in affected patients. No effective medical therapies are available for HPS, although liver transplantation reverses the syndrome in most patients. In clinical studies, the increase of nitric oxide production in the lung plays a role in HPS pathogenesis $^{8-13}$. When compared with cirrhotic control patients, exhalation NO levels increase in the cases with cirrhotic HPS.

\section{Materials and Methods}

An observational cross sectional study was conducted at S.N. Medical College and hospital, Agra in P.G. Department of Medicine. Cases for study were taken from the patients attending regular medicine outpatient department, patients admitted in hospital wards, patients attending the specialty outpatient department of gastroenterology and hepatology.

\section{Inclusion Criteria}

Patient who are known case of chronic liver disease.

1) Patient having essentially near normal chest radiograph.

2) Patient age more than $10 \mathrm{yrs}$

3) Patient who are non-smokers and not having history of chronic respiratory disease.

\section{Exclusion Criteria}

1) Patient who are critically ill.

2) Patient having lower respiratory tract infection.

3) Patient having lung parenchyma disease like tuberculosis or chronic obstructive pulmonary disease etc

4) Patient having cardiovascular disorder

5) Patient who did not give their consent to be part of study. 


\section{Observation}

Table 1 Sex Distribution

\begin{tabular}{|l|l|}
\hline Male & $80 \%$ \\
\hline Female & $20 \%$ \\
\hline
\end{tabular}

\section{sex distribution}

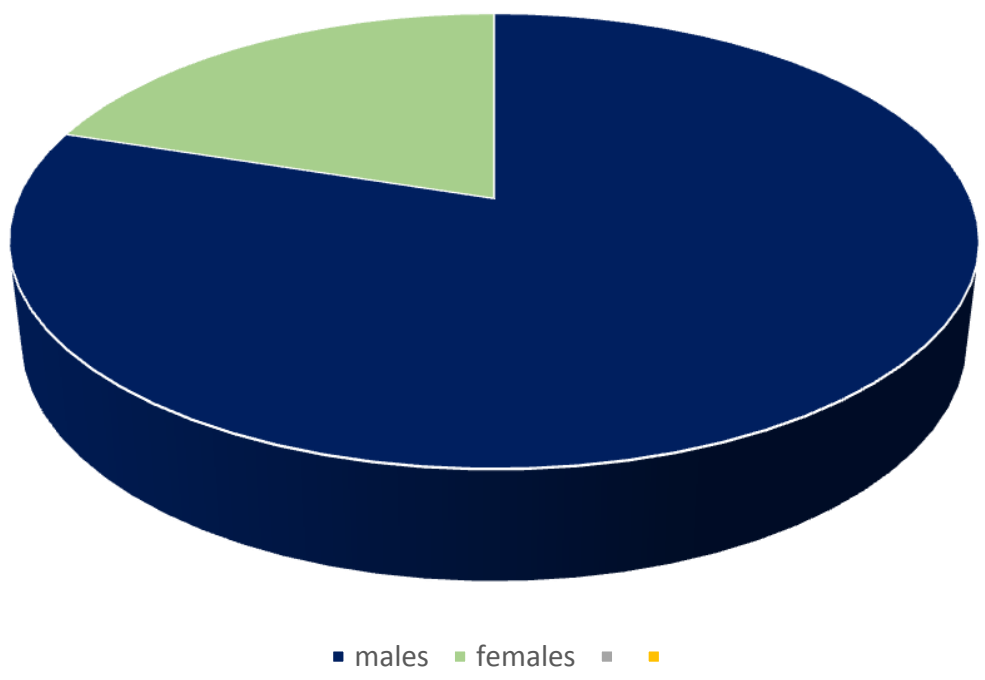

Study comprises total of 80 patients who are fulfilling the inclusion criteria, 64 were male and 12 were female as shown in pie chart.

Table 2: Distribution of patients according to age group

\begin{tabular}{|l|c|}
\hline $15-25$ yrs & $5 \%$ \\
\hline $26-35$ yrs & $10 \%$ \\
\hline $36-45$ yrs & $20 \%$ \\
\hline $46-55$ yrs & $33 \%$ \\
\hline $56-65$ yrs & $20 \%$ \\
\hline $66-75$ yrs & $14 \%$ \\
\hline
\end{tabular}

\section{Age Group}

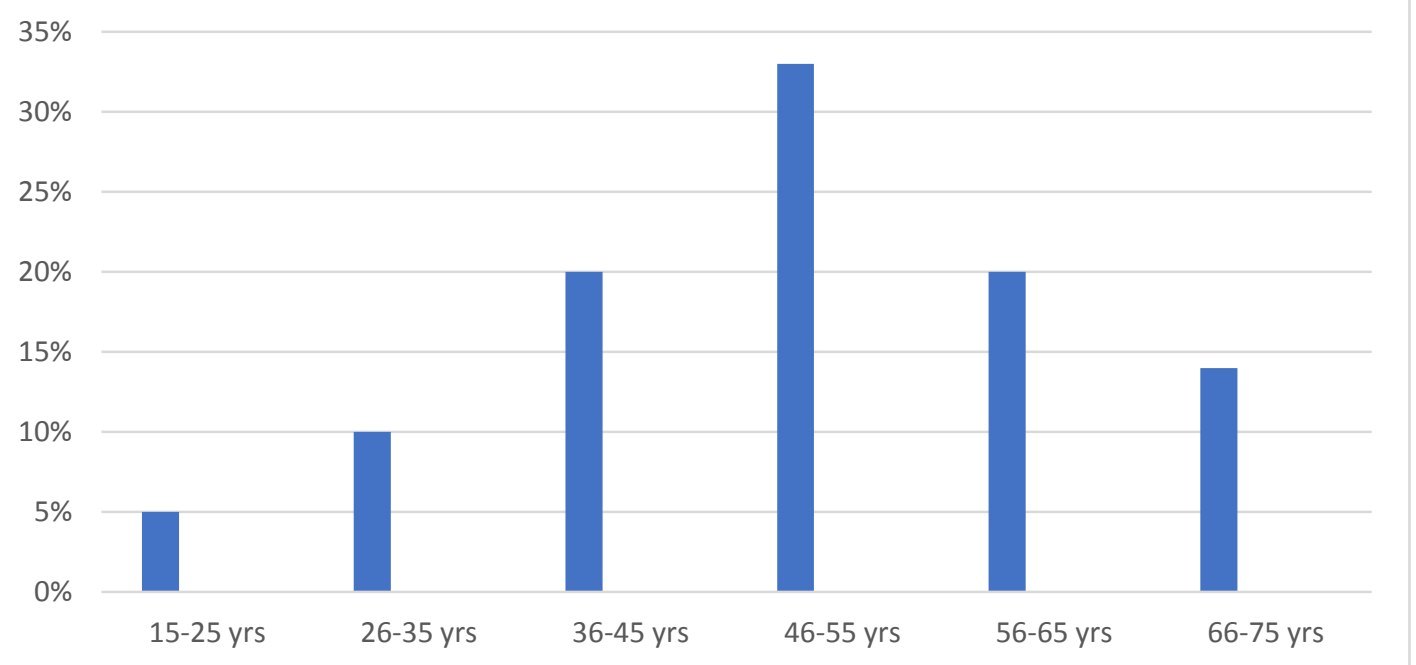


Table 3: Distribution of patients according to diagnosis

\begin{tabular}{|l|c|}
\hline CLD with PHTN & $95 \%$ \\
\hline NCPF & $2 \%$ \\
\hline EHPVO & $2 \%$ \\
\hline Others & $1 \%$ \\
\hline
\end{tabular}

\section{percentage}

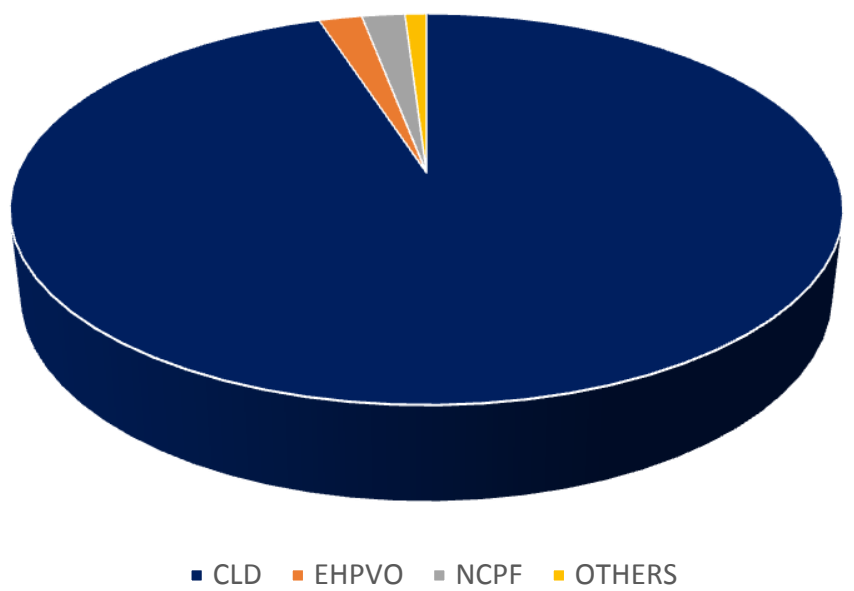

Patients are categorised as having CLD with portal hypertension, NCPF, EHPVO and others.

Maximum number of cases were CLD with portal hypertension 95\% while that of EHPVO and NCPF were $1 \%$ each.

Table 4: Distribution according to cause of CLD

Patients in various groups are divided on the basis of cause of CLD (alcohol, viral, NASH, others)

\begin{tabular}{|l|c|}
\hline Alcohol & $67 \%$ \\
\hline Viral & $18 \%$ \\
\hline NASH & $11 \%$ \\
\hline Others & $3 \%$ \\
\hline
\end{tabular}

Among causes of CLD in maximum number was alcoholic $67 \%$ of total while that of viral $18 \%$,NASH $11 \%$ others $3 \%$.

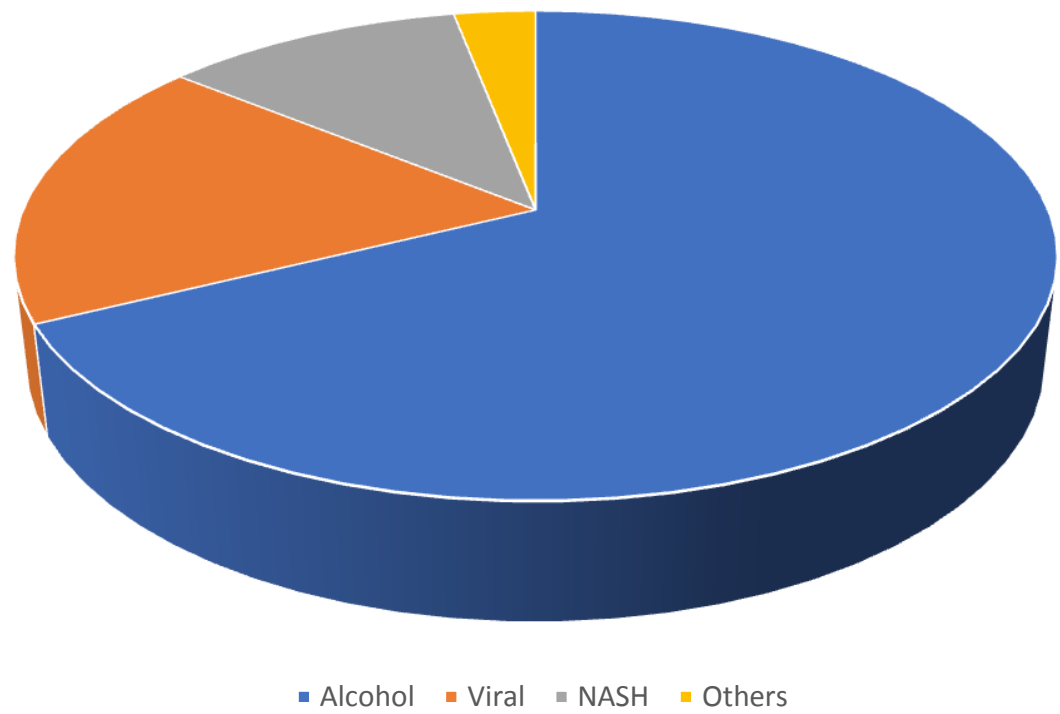


Table 5: Distribution according to ABG findings

\begin{tabular}{|l|c|}
\hline $\begin{array}{l}\text { Saturation difference in Supine and upright position } \\
(>4 \mathrm{~mm} \mathrm{Hg})\end{array}$ & $14.5 \%$ \\
\hline $\mathrm{P}(\mathrm{A}-\mathrm{a}) \mathrm{O} 2 \mathrm{~mm} \mathrm{Hg}(>15)$ & $33.3 \%$ \\
\hline Shunts on CEE & $6.6 \%$ \\
\hline
\end{tabular}

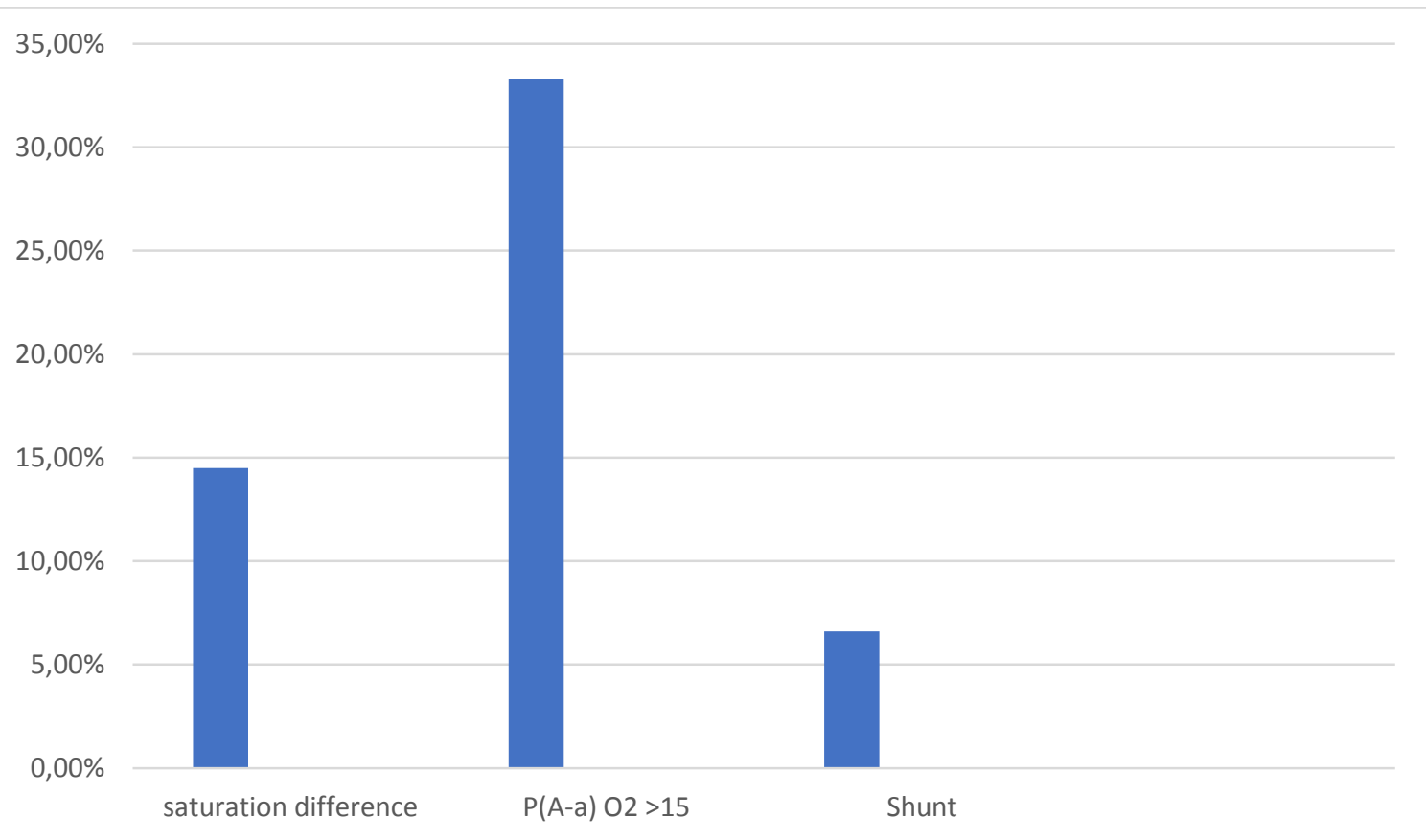

On ABG alveolar to arterial saturation difference of $>15 \mathrm{~mm}$ of $\mathrm{Hg}$ was found in $33.3 \%$ (20), on ABG analysis po2 was $80.63 \mathrm{~mm}$ of $\mathrm{Hg}$, spo2 difference of $>4 \mathrm{~mm}$ of $\mathrm{Hg}$ was found in 4 (13.3\%) patients. 4 patients were found to have shunts on CEE. So $4(6.6 \%)$ patients fulfilling the triad were assigned to have HPS. in $8(13.3 \%)$ patient out of 60 difference in spo 2 was pathological. Out of all 8 patients with pathological spo2 $6(75 \%)$ had CTP score C, while 2 had score B. out of all 8 patients with pathological spo2 difference, average of MALD score was 25.75, while in rest it was 20.19.

\section{Discussion}

Hepatopulmonary syndrome is an important complication of chronic liver disease with portal hypertension and an indication of liver transplantation. In our study 20 patients had pathological difference of alveolar to arterial oxygen saturation, 8 patient have pathological saturation difference on assuming upright posture from supine among these 6 were in CPT score C and 2 were in score B , 4 patient were found to have shunts on CEE.4 patients fulfilling diagnostic criteria are assigned in HPS.

With $\mathrm{P}$ (A-a)2>15 $\mathrm{mmHg}$ as the cut off, the prevalence in our patients 20 was higher compared with the studies of Rolla and colleagues 15 and Martinez-Palli and colleagues 12.In the study of Rolla et al more patients had a positive contrast echocardiograpy and patients were less $\begin{array}{lllll}\text { hypoxaemic (mean Pao2 } & 85.1 & \mathrm{mmHg} & \mathrm{V}\end{array}$ $71.5 \mathrm{mmHg}$ in our patients ;mean $\mathrm{P}(\mathrm{A}-\mathrm{a}) \mathrm{O} 217.8$ $\mathrm{mmHg} \mathrm{V} 18.2 \mathrm{mmHg}$ in our patients.

In Stoller et al study, HPS was diagnosed in four of 98 patients but the frequency of intrapulmonary vasodilation and arterial blood gas analysis in the remaining 94 patients were not provided.

In the study of Vedrinne and colleagues the frequency of positive contrast echocardiography and the prevalanve for HPS in cirrhotics increased by $5 \%$ and $19 \%$ respectively when the transoesophageal approach was used compared with the transthoracic procedure in concordance using the transoesophageal technique. Our study 
clearly showed $75 \%$ patients are in class $\mathrm{C}$ while $25 \%$ in class B among patients having HPS, it clearly shows a significant correlation between the severity of HPS and Child-Pugh score this is the difference of our from previously done. Alsostudy results shows correlation of $\mathrm{SpO} 2$ as an screening test to detect the presence of HPS as chances of false positive were less compare to $\mathrm{P}(\mathrm{A}-\mathrm{a}) \mathrm{O} 2$ on ABG.

\section{Conclusion}

The study concludes that proportion of patients with HPS found are $6.6 \%$ (4) out of 60 patients. clinical profile of the HPS patient as observe was patients average age was 43yrs,3(75\%) were alcoholic while $1(25 \%)$ having viral etiology almost $100 \%$ presented with ascites splenomegaly, clubbing, platypnoea. Spider angiomata were not detected may be dark complexion of our patients, on UGIE all shows oesophageal varices, all have hematemesis and malena. Out of 4,3 were in CPT score $\mathrm{C}$ and 1 in score B. Also finding suggest more stronger relationship of saturation difference as an screening test for HPS than $\mathrm{P}(\mathrm{A}-\mathrm{a}) \mathrm{O} 2$ on ABG.

\section{References}

1. Kennedy TC, Knudson RJ. Exerciseaggravated hypoxemia and orthodeoxia in cirrhosis. Chest 1977; 72: 305-309.

2. Krowka MJ. Hepatopulmonary syndrome versus portopulmonary hypertension: distinctions and dilemmas. Hepatology 1997; 25: 1282-1284.

3. Hoeper MM, Krowka MJ, Strassburg CP. Portopulmonary hypertension and hepatopulmonary syndrome. Lancet 2004; 363: 1461-1468.

4. Abrams GA, Fallon MB. The hepatopulmonary syndrome. Clin Liver Dis 1997; 1: 185-200.

5. De BK, Sen S, Biswas PK, Sanyal R, Majumdar D, Biswas J. Hepatopulmonary syndrome in inferior vena cava obstruction responding

to

cavoplasty.

Gastroenterology 2000; 118: 192-196.

6. Gupta D, Vijaya DR, Gupta R, Dhiman RK, Bhargava M, Verma J, Chawla YK. Prevalence of hepatopulmonary syndrome in cirrhosis and extrahepatic portal venous obstruction. Am J Gastroenterol 2001; 96: 3395-3399.

7. Tzovaras N, Stefos A, Georgiadou SP, Gatselis N, Papadamou G, Rigopoulou E, Ioannou M, Skoularigis I, Dalekos GN. Reversion of severe hepatopulmonary syndrome in a non cirrhotic patient after corticosteroid treatment for granulomatous hepatitis: a case report and review of the literature. World J Gastroenterol 2006; 12: 336-339.

8. Strassburg CP. Gastrointestinal disorders of the critically ill. Shock liver. Best Pract Res Clin Gastroenterol 2003; 17: 369-381

9. Zhang HY, Han DW, Wang XG, Zhao YC, Zhou X, Zhao HZ. Experimental study on the role of endotoxin in the development of hepatopulmonary syndrome. World J Gastroenterol 2005; 11: 567-572.

10. Zhang HY, Han DW, Zhao ZF, Liu MS, Wu YJ, Chen XM, Ji C. Multiple pathogenic factor-induced complications of cirrhosis in rats: a new model of hepatopulmonary syndrome with intestinal endotoxemia. World J Gastroenterol 2007; 13: 3500-3507.

11. Vallance P, Moncada S. Hyperdynamic circulation in cirrhosis: a role for nitric oxide? Lancet 1991; 337: 776-778 [PMID: $1706450 \quad$ DOI: $10.1016 / 0140-$ 6736(91)91384-7].

12. Fallon MB, Abrams GA, Luo B, Hou Z, Dai J, Ku DD. The role of endothelial nitric oxide synthase in the pathogenesis of a rat model of hepatopulmonary syndrome. Gastroenterology 1997; 113: 606-614.

13. Liu L, Zhang M, Luo B, Abrams GA, Fallon MB. Biliary cyst fluid from 
common bile duct-ligated rats stimulates endothelial nitric oxide synthase in pulmonary artery endothelial cells: a potential role in hepatopulmonary syndrome. Hepatology 2001; 33: 722-727.

14. Rolla G, Brussino L, Colagrande P, Scappaticci E, Morello M, Bergerone S, Ottobrelli A, Cerutti E, Polizzi S, Bucca C. Exhaled nitric oxide and impaired oxygenation in cirrhotic patients before and after liver transplantation. Ann Intern Med 1998; 129: 375-378.

15. Schroeder RA, Ewing CA, Sitzmann JV, Kuo PC. Pulmonary expression of iNOS and $\mathrm{HO}-1$ protein is upregulated in a rat model of prehepatic portal hypertension. Dig Dis Sci 2000; 45: 2405-2410. 